\title{
ENZIM AMILASE SEBAGAI KOMPONEN ANTAGONIS BACILLUS SUBTILIS B315 TERHADAP RALSTONIA SOLANACEARUM KENTANG
}

\author{
Nur Prihatiningsih \& Heru Adi Djatmiko \\ Fakultas Pertanian Universitas Jenderal Soedirman Kampus Karangwangkal \\ Jl. Dr. Suparno Purwokerto 52123 \\ E-mail: prihatiningsihnur@gmail.com
}

\begin{abstract}
Enzyme amylase as an antagonist component of Bacillus subtilis B315 against potato Ralstonia solanacearum. One of the antagonist mechanism of Bacillus subtilis B315 is that it produced secundary metabolites. Enzyme amylase is produced by $B$. subtilis B315 as a secondary metabolite. The aims of the research were: (1) to test mechanism of antagonistics by B. subtilis B315 against potato Ralstonia solanacearum and (2) to detect antibiosis activity of B. subtilis B315. The research was conducted in the Laboratory of Plant Protection Agriculture Faculty and Laboratory of Integrated Research of Jenderal Soedirman University from April to October 2014. The research method is an experimental with growing double layer of $B$. subtilis B315 in YPGA medium and Ralstonia solanacearum in water agar. This research used a Completely Randomized Design with 3 treatments and 8 replications. The treatments were $B$. subtilis $\mathrm{B} 1, B$. subtilis $\mathrm{B} 46$ and $B$. subtilis $\mathrm{B} 315$. The activity of antibiosis was tested by amylase activity enzyme and than it was analyzed using FTIR (Fourier Transform-infra Red). Result of the research showed that B. subtilis B315 could suppress $R$. solanacearum growth with $14 \mathrm{~mm}$ inhibition zone. Antibiosis activity of B. subtilisB315 as biological agents was showed by the production of amylase enzyme by activity of $0,802 \mathrm{unit} / \mathrm{ml}$. Analysis by FTIR was showed by the production of compound group of alkane, aldehyde, ketones, carboxylic acid, esther, amina, and amida.
\end{abstract}

Key words: amylase, Bacillus subtilis B315, Ralstonia solanacearum

\begin{abstract}
ABSTRAK
Enzim amilase sebagai komponen antagonis Bacillus subtilis B315 terhadap Ralstonia solanacearum kentang. Salah satu mekanisme antagonistik dari Bacillus subtilis B315 adalah antibiosis yaitu dihasilkannya metabolit sekunder. Beberapa contoh metabolit sekunder adalah enzim amilase, protease, chitinase dan lipase. Tujuan penelitian ini adalah: (1) menguji mekanisme antagonistik $B$. subtilis B315 terhadap $R$. solanacearum kentang dan (2) mendeteksi aktivitas antibiosis dari B. subtilis B315. Penelitian dilaksanakan di Laboratorium Perlindungan Tanaman Fakultas Pertanian Unsoed dan di Laboratorium Riset Terpadu Unsoed dari bulan April sampai dengan Oktober 2014. Metode penelitian yang digunakan adalah eksperimental dengan menumbuhkan secara berlapis $B$. subtilis B315 dalam medium YPGA dan $R$. solanacearum dalam agar air. Rancangan yang digunakan adalah acak lengkap dengan 3 perlakuan dan 8 ulangan. Perlakuan 1 adalah $B$. subtilis B1, perlakuan 2 adalah $B$. subtilis B46 dan perlakuan 3 adalah B. subtilis B315. Pengujian aktivitas antibiosis dilakukan dengan mengamati aktivitas enzim amilase dan selanjutnya mengekstrak B. subtilis B315 dengan etil asetat, untuk mendeteksi enzim yang dihasilkan yang dianalisis dengan FTIR (Fourier Transform-infra Red). Hasil penelitian menunjukkan bahwa $B$. subtilis B315 mampu menekan pertumbuhan $R$ solanacearum dengan zona hambatan $14 \mathrm{~mm}$. Aktivitas antibiosis $B$. subtilis B315 sebagai agensia hayati ditunjukkan dengan dihasilkannya enzim amilase dengan aktivitas 0,802 unit/ml. Hasil analisis dengan FTIR menunjukkan bahwa B. subtilis B315 menghasilkan senyawa kelompok alkana, aldehid, keton, asam karboksilat, ester, amina, dan amida.
\end{abstract}

Kata kunci: amilase, Bacillus subtilis B315, Ralstonia solanacearum

\section{PENDAHULUAN}

Bacillus subtilis mewakili bakteri Gram positif sebagai contoh mikroba antagonis yang berperan sebagai agensia pengendali hayati. B. subtilis adalah bakteri antagonis yang diketahui mampu mengendalikan beberapa patogen baik jamur maupun bakteri, dengan cara menghambat pertumbuhannya (Chen et al., 2012). Bakteri patogen yang telah diketahui terhambat pertumbuhannya oleh $B$. subtilis adalah Xanthomonas oryzae pv. oryzae dan Ralstonia solanacearum (Agustiansyah et al., 2013). 
Mekanisme pengendalian oleh $B$. subtilis sebagai aktivitas langsung yaitu antibiosis, parasitisme dan penginduksi ketahanan tanaman terhadap patogen serta kompetisi langsung (Janisiewicz et al., 2000). Mekanisme antibiosis terlihat dengan terbentuknya zona hambatan, yang menunjukkan adanya suatu senyawa yang dihasilkan sebagai metabolit sekunder dan berfungsi sebagai aktivitas antibiosis. Senyawa tersebut berupa enzim, toksin, dan antibiotik (Prihatiningsih \& Djatmiko, 2014). Menurut Morikawa (2006), B. subtilis mensekresikan enzim amilase, protease, pullulanase, chitinase, xylanase, dan lipase.

Penyakit layu bakteri disebabkan oleh Ralstonia solanacearum yang menyerang hampir 200 spesies tanaman dan lebih dari 50 famili (Hayward, 1991). Penyebaran penyakit layu bakteri sangat luas, karena patogennya mempunyai kisaran inang luas, termasuk patogen tular tanah. Hal inilah yang menyebabkan penyakit layu bakteri sulit dikendalikan (Hayward, 1991; Muthoni et al., 2010). Semula nama bakteri layu ini adalah Pseudomonas solanacearum, namun sejak tahun 1995 disebut Ralstonia solanacearum (Yabuuchi et al., 1995). Penyakit layu bakteri pada tanaman kentang merupakan penyakit penting kedua setelah hawar daun oleh jamur Phytophthora infestans di daerah tropis dan sub-tropis (Champoiseau et al., 2010). Kerugian hasil karena penyakit layu bakteri dapat mencapai 50-100\%, dan dapat menyebabkan kematian tanaman (Muthoni et al., 2010).

Tujuan penelitian ini adalah (1) menguji mekanisme antagonistik B. subtilis B315 terhadap $R$. solanacearum kentang dan (2) mendeteksi aktivitas antibiosis dari B. subtilis B315.

\section{METODE PENELITIAN}

Tempat dan Waktu. Penelitian ini dilaksanakan di Laboratorium Perlindungan Tanaman Fakultas Pertanian dan Laboratorium Riset Terpadu Unsoed selama 6 bulan yaitu mulai April sampai dengan Oktober 2014.

Isolat Bakteri B. subtilis dan $R$. solanacearum. Isolat $B$. subtilis yang digunakan adalah $B$. subtilis $\mathrm{B} 1$, B46 dan B315. B. subtilis B1 diisolasi dari rizosfer padi, sedangkan B46 dan B315 diisolasi dari rizosfer tanaman kentang sehat. $R$. solanacearum yang digunakan berasal dari tanaman kentang layu. Media yang digunakan untuk memelihara isolat bakteri $B$. subtilis adalah YPGA (yeast pepton glucose agar) dan YP (yeast pepton) cair, dan untuk $R$. solanacearum adalah CPG-TTC (casamino acid pepton glucosa-triphenyl tetrazolium chloride) (Lelliot \& Stead, 1987; Goto, 1992).

Pengujian Penghambatan B. subtilis in vitro. Pengujian penghambatan $B$. subtilis terhadap $R$. solanacearum in vitro dilakukan dengan perlakuan 3 isolat B. subtilis B1, B46 dan B315 menggunakan metode yang dikemukakan oleh Ghosh et al. (2007) dengan dua lapis medium. Perlakuan ini diulang 8 kali menggunakan Rancangan Acak Lengkap.

Aktivitas Antibiosis B. subtilis B315 terhadap $R$. solanacearum. Setelah pengujian in vitro diketahui bahwa $B$. subtilis mampu menghambat pertumbuhan $R$. solanacearum, maka selanjutnya dilakukan uji amilase dengan menggoreskan koloni B. subtilis B315 pada medium hidrolisis pati (Lelliot \& Stead, 1987). Analisis enzim amilase yang dihasilkan B. subtilis B315 dilakukan setelah mendapatkan persamaan regresi dari nilai absorbansi larutan standar glukosa. Aktivitas enzim amilase dihitung berdasarkan persamaan regresi linear larutan standar glukosa dengan memasukkan nilai absorbansi sampel, lama inkubasi dan jumlah enzim yang digunakan. Kemudian aktivitas enzim amilase dihitung berdasarkan inkubasi selama 30 menit dan diukur dengan spektrofotometri pada panjang gelombang $275 \mathrm{~nm}$. Selanjutnya dilakukan ekstraksi dengan etil asetat untuk melihat senyawa apa yang dihasilkan oleh $B$. subtils B315 sebagai karakter aktivitas antibiosis (Kumar et al., 2009).

B. subtilis B315 ditumbuhkan pada medium YP cair digojog selama 3 hari dengan kecepatan $250 \mathrm{rpm}$, kemudian disentrifuse pada suhu $4{ }^{\circ} \mathrm{C}$ selama 15 menit. Supernatan bebas sel yang diperoleh diekstrak dengan etil asetat, kemudian diuapkan dengan vacum rotary evaporator pada suhu $77^{\circ} \mathrm{C}$. Crude extract kemudian dideterminasi gugus fungsinya sebagai senyawa antibakteri dengan FTIR (Fourier Transform Infrared Spectrum) pada bilangan gelombang 4000-1200 $\left(\mathrm{cm}^{-1}\right)$. Deteksi gugus fungsi dilakukan dengan FTIR yang menunjukkan aktivitas B. subtilis B315 sebagai mekanisme antibiosis dalam pengendalian patogen, seperti metode yang dilakukan oleh Kumar et al. (2009) untuk mendeteksi senyawa antifungal yang dihasilkan oleh B. subtilis MTCC-8114.

\section{HASIL DAN PEMBAHASAN}

Penghambatan pertumbuhan $R$. solanacearum oleh $B$. subtilis B315 dapat dilihat dalam Tabel 1. Tiga isolat $B$. subtilis menunjukkan perbedaan sangat nyata 
pada penghambatan terhadap $R$. solanacearum. Bacillus subtilis B315 menunjukkan penghambatan terbaik terhadap $R$. solanacearum dengan zona hambatan $14 \mathrm{~mm}$.

Zona hambatan yang terbentuk menunjukkan bahwa mekanisme $B$. subtilis sebagai agensia hayati adalah antibiosis (Gambar 1). Hasil pengamatan uji antibiosis B. subtilis B315 terhadap $R$. solanacearum menunjukkan zona hambatan terbesar $14 \mathrm{~mm}$ (Prihatiningsih \& Djatmiko, 2014). Hasil penelitian Kumar et al. (2009) menunjukkan bahwa B. subtilis MTCC-8114 yang diisolasi dari sampel tanah menunjukkan zona hambatan 14-16 mm dengan metode inokulasi spot.
Zona terang yang terbentuk di sekitar goresan $B$. subtilis B315 pada medium hidrolisis pati ditunjukkan dalam Gambar 2. Menurut Das et al. (2011), B. subtilis mampu menghasilkan enzim alfa amilase. Dikatakan bahwa bakteri yang menghasilkan enzim amilase tergantung pada tipe strain, komposisi medium, metode kultivasi, pertumbuhan sel, nutrisi yang dibutuhkan, ion logam, $\mathrm{pH}$, suhu, waktu inkubasi, termostabilitas serta terjaga dari kontaminasi selama fermentasi.

Senyawa yang dihasilkan B. subtilis B315 dapat terdeteksi setelah kultur $B$. subtilis bebas sel diekstrak dengan etil asetat. Analisis enzim amilase yang dihasilkan B. subtilis $\mathrm{B} 315$ berdasarkan persamaan regresi dari nilai absorbansi larutan standar glukosa (Gambar 3).

Tabel 1. Penghambatan pertumbuhan $R$. solanacearum oleh B. subtilis

\begin{tabular}{cc}
\hline Perlakuan B. subtilis & Zona hambatan terhadap $R$. solanacearum $(\mathrm{mm})$ \\
\hline B1 & $5,0 \mathrm{c}$ \\
B46 & $12,6 \mathrm{~b}$ \\
B315 & $14,0 \mathrm{a}$ \\
\hline
\end{tabular}

Angka yang diikuti oleh huruf yang sama dalam kolom yang sama menunjukkan tidak berbeda nyata pada uji Newman-Keuls $5 \%$.

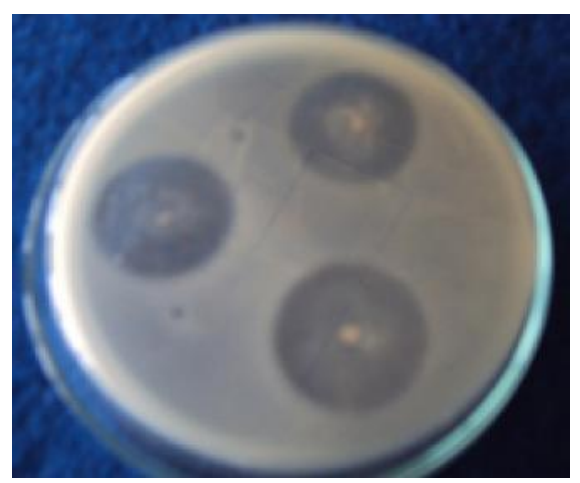

Gambar 1. Penghambatan B. subtilis B315 terhadap R. solanacearum

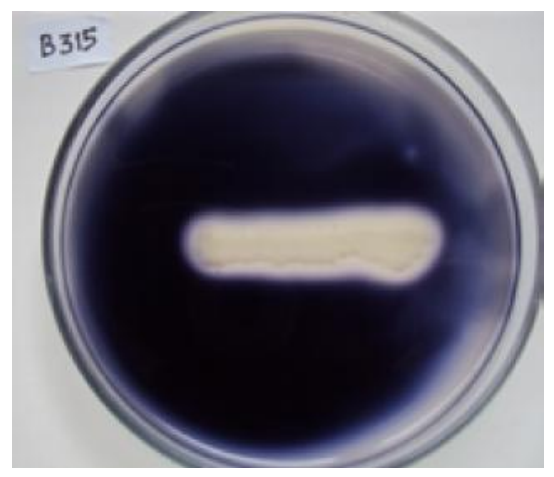

Gambar 2. Zona terang di sekitar koloni B. subtilis B315 pada uji hidrolisis pati 
Hasil perhitungan enzim amilase menunjukkan aktivitas sebesar 0,802 unit/ml setiap 30 menit dengan panjang gelombang $275 \mathrm{~nm}$ (Tabel 2).

Menurut Barus et al. (2013), Bacillus sp. menghasilkan amilase dari tape (fermentasi cassava) dengan aktivitas berkisar 4,8-29,1 unit/ml pada suhu $37{ }^{\circ} \mathrm{C}$. Bacillus sp. terdistribusi secara luas dan baik digunakan sebagai agens pemacu pertumbuhan tanaman (PGPR), dan umumnya ada di rizosfer. Bacillus sp. meningkatkan pertumbuhan tanaman dengan melenyapkan atau mengendalikan patogen dengan aktivitas antimikrobial yang unik termasuk menghasilkan antibiotik (Awais et al., 2007) dan toksin (Mukry et al., 2010), serta enzim hidrolisis seperti $\alpha$-amylase dan $\beta$ galactosidase yang dapat meningkat pada substrat seperti jagung, gandum, dan beras dibandingkan dengan medium yang komersial (Konsoula \& Liakopoulou-Kyriakides, 2007).

Enzim ini selain berguna dalam industri ternyata mampu meningkatkan pertahanan tanaman terhadap serangan nematoda, jamur dan bakteri patogen bahkan terhadap insekta. Aktivitas B. subtilis antara lain sebagai pelarut fosfat, pengoksidasi elemen sulfur menjadi sulfat, aktivitas selulase dan amilase mampu menghambat jamur Fusarium oxysporum 25-34\% dan Botryodiplodia theobromae 100\% (Swain \& Ray, 2009). Perhitungan enzim amilase dilakukan dengan terlebih dahulu menentukan persamaan regresi absorbansi glukosa standar (Gambar 3).

Enzim amilase adalah enzim yang dapat diperoleh dari tanaman, binatang maupun mikroba yang berperan dalam metabolisme karbohidrat. Diantara mikroba,

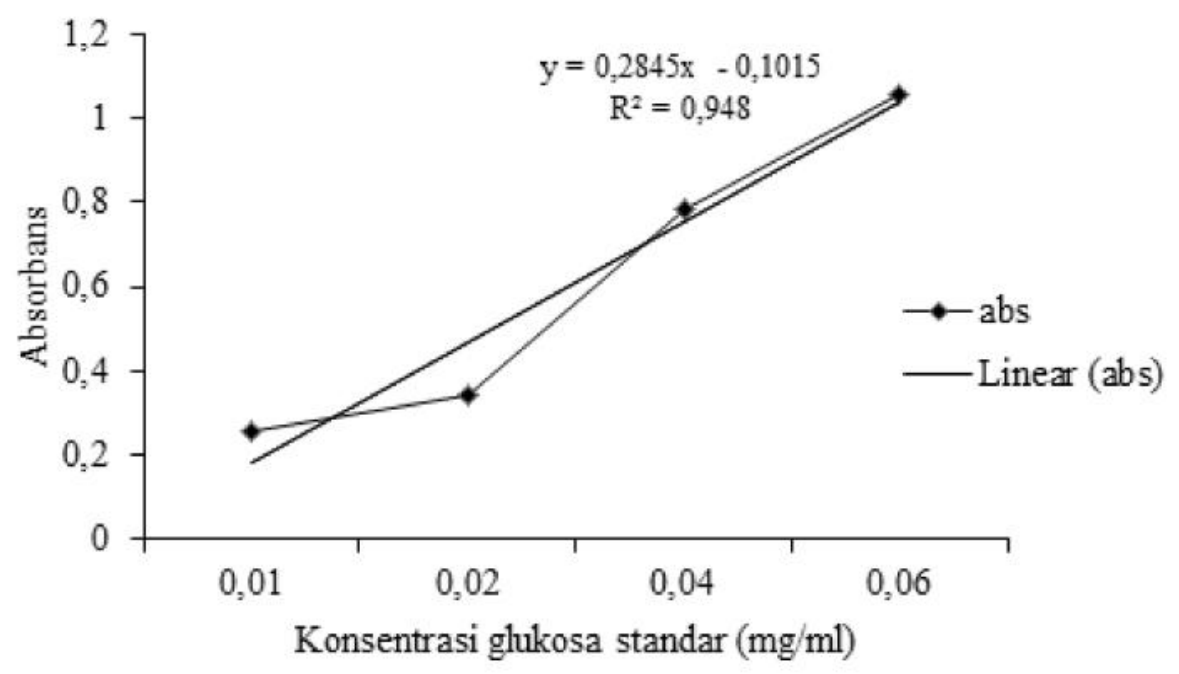

Gambar 3. Regresi absorbansi glukosa standar

Tabel 2. Nilai aktivitas enzim amilase B. subtilis B315

\begin{tabular}{|c|c|c|c|c|}
\hline Sampel & $\begin{array}{c}\text { Nilai absorbans } \\
\lambda 660 \mathrm{~nm}\end{array}$ & $\begin{array}{c}\text { X (Nilai aktivitas amilase) } \\
{\text { dari persamaan regresi }{ }^{\text {a) }}}_{(\text {unit } / \mathrm{ml})}\end{array}$ & $\begin{array}{l}\mathrm{X} \text { (Nilai aktivitas } \\
\text { amilase) dari rumus } \\
\text { (unit/ml) : } 0,18^{\mathrm{b})}\end{array}$ & $\begin{array}{l}X(\text { Nilai aktivitas } \\
\text { amilase })^{\mathrm{c})}: 30 \times 2 \\
\quad(\text { unit } / \mathrm{ml})\end{array}$ \\
\hline 1 & 0,703 & 2,8278 & 11,717 & 0,781 \\
\hline 2 & 0,720 & 2,8875 & 12,048 & 0,803 \\
\hline \multirow[t]{2}{*}{3} & 0,734 & 2,9367 & 12,327 & 0,822 \\
\hline & & & Rata-rata & 0,802 \\
\hline
\end{tabular}

a) Nilai $X$ diperoleh dari persamaan regresi $Y=-0,1015+0,2845 \mathrm{X}$; ${ }^{\text {b) }}$ Dibagi 0,18 karena satu unit aktivitas enzim amilase didefinisikan sebanyak $0,18 \mathrm{mg}$ gula pereduksi $(1 \mathrm{~mol})$ yang dibebaskan per $\mathrm{ml}$ enzim pada kondisi

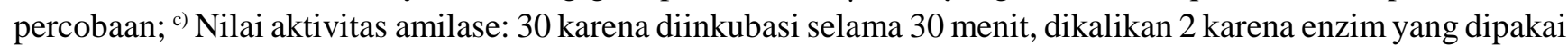
$0,5 \mathrm{ml}$. 
Bacillus sp. digunakan secara luas karena menghasilkan $\alpha$-amylase dan termostabil (Sankaran \& Ravikumar, 2011). Fungsi enzim amilase dalam pengendalian penyakit tanaman adalah sebagai inhibitor, yang melimpah pada sayuran, umbi dan serealia dan secara efisien meningkatkan ketahanan tanaman terhadap patogen seperti jamur (Rekha \& Padmaja, 2002).

Fungsi enzim dalam pengendalian penyakit tanaman adalah sebagai mekanisme antibiosis yang dapat menghambat dan atau mematikan patogen yang disebut dengan bakteriostatik dan bakterisidal (Goto, 1992). Enzim yang dihasilkan oleh tanaman misalnya enzim $\alpha$-amilase yang dihasilkan oleh tanaman Phaseolus vulgaris dapat berfungsi untuk meningkatkan resistensi terhadap serangan hama penggerek Callosobruchus maculatus dan penggerek pada kacang C. chinensis (Franco et al., 2002). Selanjutnya dikatakan bahwa tanaman dapat menghasilkan senyawa untuk pertahanan antara lain antibiotik, alkaloid, terpen, glikosida atau proteic seperti chitinase, $\beta$-1-3 glukanase, lektin, arselin, visilin, systein dan enzim penghambat. Enzim inhibitor (penghambat) dapat merusak sistem pencernaan insekta, cairan pencernaan $\alpha$-amilase dan proteinase. $B$. subtilis menghasilkan enzim amilase dan selulase, pelarut fosfat, pengoksidasi sulfur, pemacu pertumbuhan tanaman dan pengendali hayati (Swain \& Ray, 2009).

Analisis ekstrak B. subtilis B315 dengan FTIR menunjukkan bilangan gelombang dan nilai transmitan dapat dilihat pada Gambar 4, yang menunjukkan nilai daerah bilangan gelombang dengan gugus fungsi yang terbentuk oleh B. subtilis B315 dan dimasukkan ke dalam kelompok senyawa yang dihasilkan menurut Skoog et al. (1998 dalam Bambang, 2011).

Berdasarkan spektrum FTIR dan hasil analisis gugus fungsi dari B. subtilis B315, maka jenis gugus fungsi menurut bilangan gelombang adalah seperti tersaji pada Tabel 3. Gugus fungsi alkana $(\mathrm{C}-\mathrm{H})$ pada bilangan gelombang 2981,18 $\mathrm{cm}^{-1}$, gugus fungsi aldehid, keton, asam karboksilat, dan ester $(\mathrm{C}=\mathrm{O})$ pada bilangan

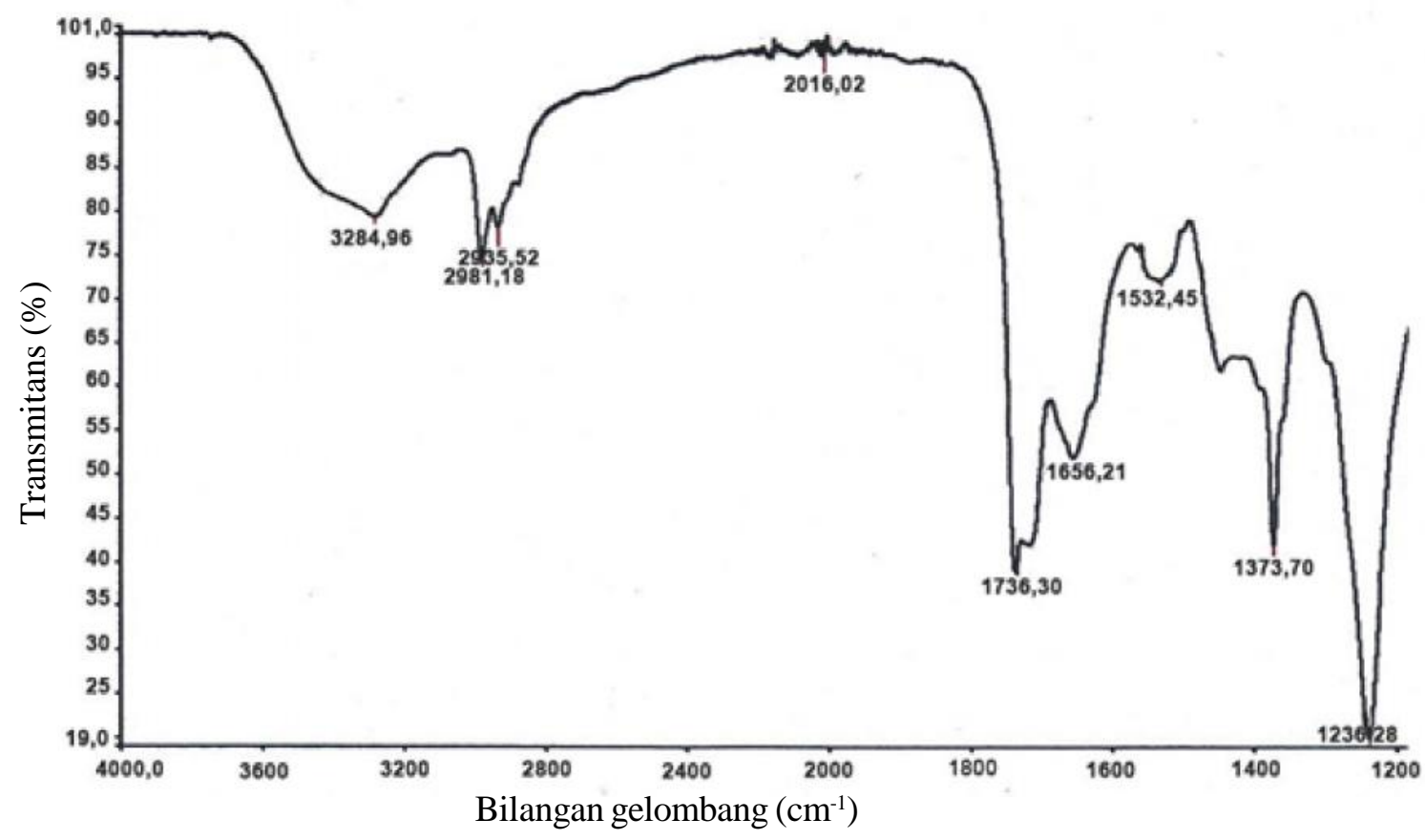

Gambar 4. Spektrum FTIR dari ekstrak B. subtilis B315

Tabel 3. Gugus fungsi dan senyawa yang dihasilkan oleh B. subtilis B315 berdasarkan bilangan gelombang yang dianalisis dengan FTIR

\begin{tabular}{cccc}
\hline Bilangan gelombang $\left(\mathrm{cm}^{-1}\right)$ & Gugus fungsi & Senyawa & Intensitas \\
\hline 2981,18 & $\mathrm{C}-\mathrm{H}$ & Alkana & Kuat \\
1736,30 & $\mathrm{C}=\mathrm{O}$ & Aldehid, Keton, Asam Karboksilat, Ester & Kuat \\
1373,70 & $\mathrm{C}-\mathrm{H}$ & Alkana & Kuat \\
1235,28 & $\mathrm{C}-\mathrm{O}$ & Amina, Amida & Kuat \\
\hline
\end{tabular}


gelombang 1736,30 $\mathrm{cm}^{-1}$ dan gugus fungsi alkana (CH) pada bilangan gelombang $1373,70 \mathrm{~cm}^{-1}$, serta gugus fungsi amina, amida $(\mathrm{C}-\mathrm{N})$ pada bilangan gelombang $1235,28 \mathrm{~cm}^{-1}$.

\section{SIMPULAN}

Berdasarkan uraian tersebut di atas dapat disimpulkan bahwa $B$. subtilis $\mathrm{B} 315$ dapat menghambat $R$. solanacearum secara in vitro dengan zona hambatan $14 \mathrm{~mm}$. B. subtilis B315 menghasilkan enzim amilase sebagai mekanisme antibiosis dengan aktivitas 0,802 unit $/ \mathrm{ml}$. B. subtilis B315 menghasilkan senyawa kelompok alkana, aldehid, keton, asam karboksilat, ester, amina, dan amida.

\section{SANWACANA}

Ucapan terima kasih disampaikan kepada Direktorat Jenderal Pendidikan Tinggi atas dana yang diberikan melalui Hibah Penelitian Desentralisasi pada skim Penelitian Fundamental pada tahun 2014.

\section{DAFTAR PUSTAKA}

Agustiansyah, Ilyas S, Sudarsono, \& Machmud M. 2013. Karakterisasi rizobakteri yang berpotensi mengendalikan bakteri Xanthomonas oryzae pv. oryzae dan meningkatkan pertumbuhan tanaman padi. J. HPT Tropika 13(1): 42-51.

Awais M, Shah AA, Hameed A, \& Hasan F. 2007. Isolation, identification and optimization of bacitracin produced by Bacillus sp. Pak. J. Bot. 39(4): 1303-1312.

Bambang. 2011. Instrumen FTIR dan membaca spektra FTIR. (On-line) http:// www.anekakimia. blogspot.com /2011/06. Diakses tanggal 23 Oktober 2014.

Barus T, Kristani A, \& Yuliandi A. 2013. Diversity of amylase-producing Bacillus spp. from "Tape" (fermented cassaca). Hayati J. Biosciences 20(2): 94-98.

Champoiseau PG, Jones JB, Momol TM, Pingsheng J, Allen C, Norman DJ, \& Caldwell K. 2010. Ralstonia solanacearum Race 3 biovar 2 causing brown rot of potato, bacterial wilt of tomato and southern wilt of geranium. American Phytopathological Society. Madison, WI.
Chen Y, Yan F, Chai Y, Liu H, Koiter R, Losick R, \& Guo J. 2012. Biocontrol of tomato wilt disease by Bacillus subtilis isolates from natural environments depends on conserved genes mediating biofilm formation. Environmental Microbiology. Society for Microbiology and Blackwell Publishing Ltd.

Das S, Singh S, Sharma V, \& Soni ML. 2011. Biotechnological applications of industrially important amylase enzyme. Int. J. Pharm Bio. Sci. 1(2): 486-496.

Franco OL, Rigden DJ, Melo FR, \& Grossi-de-Sa MF. 2002. Plant $\alpha$-amylase inhibitor and their interaction with insect $\alpha$-amylases Structure, function and potential for crop protection. FEBS J. 269: 397-412.

Ghosh S, Sinha A, \& Sahu C. 2007. Isolation of putative probionts from the intestines of Indian mayor carps. Isr. J. Aquacult.-Bamid. 59(3): 127-132.

Goto M. 1992. Fundamentals of Bacterial Plant Pathology. Academic Press, INC. New York.

Hayward AC. 1991. Biology and epidemiology of bacterial wilt caused by Pseudomonas solanacearum. Annu. Rev. Phytopathol. 29: 6587.

Janisiewicz WJ, Tworkoski TJ, \& Sharer C. 2000. Characterizing the mechanism of biological control of postharvest diseases on fruits with a simple method to study competition for nutrients. Phytopathology 90(11): 1196-1200.

Konsoula Z \& Liakopoulou-Kyriakides M. 2007. Coproduction of $\alpha$-amylase and $\beta$-galactosidase by Bacillus subtilis in complex organic substrates. Bioresource Technol. 98(1): 150-157.

Kumar A, Saini P, \& Shrivastava JN. 2009. Production of peptide antifungal antibiotic and biocontrol activity of Bacillus subtilis. Indian J. Exp. Biol.. 47(1): 57-62.

Lelliot RA \& Stead DE. 1987. Methods for the Diagnosis of Bacterial Diseases of Plant. British Society for Plant Pathology by Blackwel Scientific Publication, Melbourne.

Morikawa M. 2006. Beneficial biofilm formation by industrial bacteria Bacillus subtilis and related species. J. Biosci. Bioeng. 101(1): 1-8. 
Mukry SN, Ahmed A, \& Khan SA. 2010. Screening and partial characterization of hemolysins from Bacillus sp.: strain S128 \& S144 are hemolysin B (HBL) producers. Pak. J. Bot. 42(1): 463472.

Muthoni J, Mbiyu MW, \& Nyamongo DO. 2010. A review of potato seed systems and germplasm conservation in Kenya. J. Agr. Food Information 11(2): 157-167.

Prihatiningsih N \& Djatmiko HA. 2014. Karakter Bacillus subtilis B315 sebagai antibakteri Ralstonia solanacearum dan antijamur Colletotrichum sp. Seminar Nasional Pengendalian Penyakit pada Tanaman Pertanian Ramah Lingkungan. Tanggal 20 September 2014. PFI Joglosemar di Fakultas Pertanian UGM Yogyakarta.

Rekha MR \& Padmaja G. 2002. Alpha-amylase inhibitor changes during processing of sweet potato and taro tubers. Plant Food Hum. Nutr. 57: 285294.
Sankaran K \& Ravikumar S. 2011. Enhanced production and immobilization of alpha amylase using recombinant Bacillus subtilis (MTCC 2423). Int. J. Curr. Res. 2(1): 176-181.

Swain MR \& Ray RC. 2009. Biocontrol and other beneficial activities of Bacillus subtilis isolated from cowdung microflora. Microbiol. Res. 164(2): 121-130.

Yabuuchi E, Kosako Y, Yano I, Hotta H, \& Nishiuchi Y. 1995. Transfer of two Burkholderia and an Alcaligenes species to Ralstonia gen. nov.: proposal of Ralstonia pickettii (Ralston, Palleroni and Dondoroff 1973) comb. nov., Ralstonia solanacearum (Smith 1896) comb. nov. and Ralstonia eutropha (Davis 1969) comb. nov. Microbiol. Immunol. 39(11): 897-904. 